\title{
ANALISIS PERBANDINGAN KINERJA CAR, ROA, NIM, BOPO DAN LDR PERBANKAN SYARIAH DENGAN PERBANKAN KONVENSIONAL
}

\author{
Sustari Alamsyah \\ doni.alamsyah06@gmail.com \\ Sheily Dwi Meilyda \\ Sheilydwi5@gmail.com \\ Universitas Muhammadiyah Tangerang
}

\begin{abstract}
The research objective is to compare the financial performance of Islamic banking with conventional banking. The financial performance used is the ratio of CAR, ROA, NIM, $O E O I$ and LDR. The research design is descriptive quantitative with the unit of analysis of financial ratios. The population used is syari'ah and conventional banking which are registered with Bank Indonesia. The sampling method was purposive sampling, and obtained 4 Islamic banks and 4 conventional banks. The data analysis technique is descriptive statistical analysis and to answer the proposed hypothesis using the Independent sample t-test. The results of the study found that there were differences in the financial performance of Islamic banks and conventional banks using ROA, NIM, and BOPO ratios. Meanwhile, the CAR and LDR ratios have no difference. In terms of financial ratios, conventional banking performance is better than the financial performance of syari'ah banks. The implication of this research proves that conventional banking is more in demand by the public when compared to syari'ah banking, this can be seen from the value of financing and financial transactions which are more dominated by conventional banks.
\end{abstract}

Keywords: CAR, ROA, NIM, BOPO and LDR

\begin{abstract}
ABSTRAK
Tujuan penelitian membandingkan kinerja keuangan perbankan syariah dengan perbankan konvensional. Kinerja keuangan yang digunakan yaitu rasio CAR, ROA, NIM, BOPO dan LDR. Desain penelitian bersifat deskriptif kuantitatif dengan unit analisisnya rasio keuangan. Populasi yang digunakan yaitu perbankan syari'ah dan konvensional terdaftar di Bank Indonesia. Metode pengambilan sampel yaitu purposive sampling, dan diperoleh 4 bank syariah dan 4 bank konvensional. Teknik analisis data yaitu analisis statistik deskriptif dan untuk menjawab hipotesis yang diajukan menggunakan Independent sample t-test. Hasil penelitian menemukan bahwa terdapat perbedaan kinerja keuangan bank syariah dan bank konvensional dengan menggunakan rasio ROA, NIM, dan BOPO. Sedangkan rasio CAR dan LDR tidak memiliki perbedaan. Ditinjau dari rasio keuangan, kinerja perbankan konvensional lebih baik jika dibandingkan dengan kinerja keuangan perbankan syari'ah. Implikasi penelitian membuktikan bahwa perbankan konvensional lebih diminati oleh masrakat jika dibandingkan dengan perbankan syari'ah,hal ini dapat dilihat dari nilai pembiayaan dan transaksi keuangan yang lebih didominasi oleh bank konvensional.

Kata Kunci : CAR, ROA, NIM, BOPO dan LDR.
\end{abstract}




\section{PENDAHULUAN}

\section{Latar Belakang Masalah}

Bank merupakan lembaga keuangan yang mempunyai peran dalam memajukan dan meningkatkan perekonomian suatu negara. Perbankan menjalankan fungsi ekonomi dan keuangan (Kasman \& Carvallo, 2013). sebagai fungsi ekonomi bank mendukung lalu lintas pembayaran dan penyaluran kredit dalam upaya menggerakkan perekenomian suatu negara. sedangkan sebagai fungsi keuangan, bank memberikan fasilitas penyimpanan dan pembiayaan ke masyarakat. Bank dalam Pasal 1 ayat (2) UU No. 10 Tahun 1998 tentang perubahan UU No. 7 Tahun 1992 tentang perbankan adalah badan usaha yang menghimpun dana dari masyarakat dalam bentuk simpanan dan menyalurkannya kepada masyarakat dalam bentuk kredit dan atau bentuk-bentuk lain dalam rangka meningkatkan taraf hidup rakyat banyak, sehingga fungsi perbankan yaitu sebagai lembaga intermediasi yang menghimpun dan menyalurkan dana dari dan ke masyarakat.

Masalah muncul ketika perbankan tidak lagi berjalan sesuai dengan fungsinya, seperti pada kasus Bank bukopin pada bulan Juni 2020 yang mengalami kesulitan likuiditas. Hal ini berdampak pada kesulitan lalu lintas pembayaran yang menyebabkan kerugian dari pihak nasabah, termasuk kesulitan untuk mengambil dana yang disimpan di Bank (CNBC, 2020). Hal ini berimplikasi pada buruknya kinerja perbankan yang pada akhirnya menurunkan tingkat kepercayaan masyarakat. Selain masalah tersebut, terdapat juga permasalahan terkait kecurangan yang dilakukan oleh pegawai bank yang menambah daftar buruk ketidakpercayaan nasabah pada perbankan.

Di Indonesia, terdapat dua jenis bank yaitu bank konvensional dan syariah (Wahono dan Vivin, 2017). Bank konvensional merupakan bank yang melaksanakan kegiatan usahanya secara konvensional dalam kegiatannya memberikan jasa perbankan, seperti menjalankan lalu lintas pembayaran, penyaluran kredit, pembiayaan dan produkproduk jasa perbankan (Arianto, 2016). Sedangkan bank syariah merupakan bank yang menjalankan kegiatan operasionalnya berdasarkan prinsip-prinsip syariah yang dalam kegiatannya memberikan jasa yang sama dengan perbankan konvensional, hanya saja dalam hal transaksinya harus sesuai dengan aturan syari'ah. Undang-undang perbankan mengharuskan Bank Indonesia untuk menyiapkan berbagai perangkat dan ketentuan serta fasilitas penunjang yang mendukung legalitas operasional bank syariah, sehingga 
memberikan landasan hukum dan kesempatan yang luas dalam pengembangan perbankan syariah di Indonesia.

Dalam menjalankan operasionalnya, Bank syariah tidak menggunakan sistem bunga sebagai instrumen untuk memperoleh pendapatan atau membebankan bunga atas kompensasi pemberian dana, akan tetapi sebagai gantinya diterapkan sistem profit sahring. Sistem ini memungkinkan nasabah mengawasi kinerja bank syariah secara langsung melalui sistem monitoring atas jumlah bagi hasil yang dapat diperoleh. Jika keuntungan bank semakin tinggi, maka bagi hasil yang diterima nasabah juga akan semakin tinggi, dan juga sebaliknya. Nilai bagi hasil rendah atau menurun dalam waktu yang cukup lama, akan menjadi indikator buruknya pengelolaan bank. Kondisi ini merupakan early warning terkait transparansi dan akuntabilitas yang dapat diketahui nasabah. Sedangkan pada bank konvensional, nasabah dapat menilai kinerja hanya dari indikator tingkat bunga yang diperoleh.

Faktor utama yang harus diperhatikan oleh perbankan konvensional maupun syariah agar terus bertahan hidup yaitu penilaian terkait kesehatan bank melalui kinerja keuangan. Kinerja yang baik ditandai dengan pencapaian profitabilitas yang tinggi, sedangkan kinerja buruk terkorelasi melalui kerugian yang dialami oleh perusahaan. Kinerja keuangan bermanfaat untuk mengevaluasi kinerja di masa lalu dengan melakukan berbagai analisis, sehingga diperoleh posisi keuangan perusahaan yang mewakili kondisi realitas perusahaan. Kinerja keuangan dapat menunjukan sesuatu yang berhubungan dengan kekuatan serta kelemahan perusahaan. Kekuatan tersebut dipahami agar dapat dimanfaatkan dalam menunjang keberhasilan perusahaan, sedangkan kelemahan harus diketahui agar dapat dilakukan langkah perbaikan. Melalui kinerja keuangan yang baik diharapkan perbankan dapat menjalankan fungsinya dengan baik yang pada akhirnya memberikan kontribusi nyata dalam kemajuan ekonomi negara.

Motivasi penelitian yaitu: pertama, membandingkan kinerja keuangan bank syariah dengan bank konvensional agar memberikan penjelasan terkait rasio keuangan CAR, ROA, NIM, BOPO dan LDR. Kedua, melihat perbedaan kinerja dan mencoba menyimpulkan rasio apa yang lebih baik diantara kedua bank tersebut. Ketiga, membuktikan penelitian terdahulu yang masih mendapatkan hasil kontradiktif terkait penilaian kesehatan bank seperti yang dilakukan oleh Jahja dan Iqbal (2012), Muchlis dan Umardani (2016), serta Sovia, Saifi dan Husaini (2016). 


\section{TINJAUAN PUSTAKA}

\section{Bank Konvensional}

Bank konvensional dapat didefinisikan berdasarkan pasal 1 ayat 3 UndangUndang No. 10 tahun 1998 yaitu bank yang melaksanakan kegiatan usahanya secara konvensional (tidak terikat pada suatu perinsip apapun) dalam kegiatannya memberikan jasa lalu lintas pembayaran dan pembiayaan. Bank umum adalah lembaga keuangan yang kegiatan utamanya adalah menghimpun dana dari masyarakat dan menyalurannya kembali dana tersebut ke masyarakat serta memberikan jasa bank lainnya (Kasmir, 2013:25). Dalam menentukan harga dan mencari keuntungan, bank yang berdasarkan prinsip konvensional menggunakan dua metode, yaitu:1. Menetapkan tingkat bunga sebagai harga untuk produk simpanan seperti tabungan, giro dan deposito. Demikian juga untuk produk pembiayaannya ditetapkan tingkat suku bunga tertentu. Penentuan tingkat suku bunga ini dikenal dengan istilah Spread Based. 2) Untuk jasa-jasa bank lainnya, pihak perbankan menerapkan berbagai biaya-biaya dalam nominal atau prosentase tertentu. System pengenaan biaya ini dikenal dengan istilah Fee Based.

\section{Bank Syariah}

Bank Islam atau selanjutnya disebut dengan Bank Syariah, adalah bank yang beroperasi dengan tidak mengandalkan pada bunga. Bank syariah juga dapat diartikan sebagai lembaga keuangan/perbankan yang operasional dan produknya dikembangkan berlandaskan Al-Qur'an dan Hadits Nabi SAW. Antonio membedakan menjadi dua pengertian, yaitu Bank Islam dan Bank yang beroperasi dengan prinsip syariah Islam. Bank Islam adalah bank yang beroperasi dengan prinsip syariah Islam dan bank yang tata cara beroperasinya mengacu kepada ketentuan- ketentuan Al-Qur'an dan Hadits. Bank yang beroperasi sesuai dengan prinsip syariah Islam adalah bank yang dalam beroperasinya mengikuti ketentuan-ketentuan syariah Islam, khususnya yang menyangkut tata cara bermuamalat secara Islam (Syafi'i dan Antonio, 2014).

\section{Kinerja Keuangan}

Kinerja keuangan merupakan pencapaian capaian keberhasilan manajemen dalam mengelola perusahaan yang dapat dilihat melalui laporan keuangan. Menurut Rudianto (2013:189), kinerja keuangan yaitu hasil atau prestasi yang telah dicapai oleh manajemen perusahaan dalam menjalankan fungsinya mengelola aset perusahaan secara efektif selama periode tertentu. Menurut Fahmi (2012:2) kinerja keuangan adalah suatu 
analisis yang dilakukan untuk melihat sejauh mana perusahaan telah melaksanakan dengan menggunakan aturan - aturan pelaksanaan keuangan secara baik dan benar seperti dalam membuat suatu laporan keuangan yang telah memenuhi standar atau ketentuan dalam SAK (standar akuntansi keuangan) atau GAAP (generally accepted accounting principl) dan lainnya.

\section{Rasio Keuangan}

Menurut Kasmir (2016: 104) Rasio keuangan merupakan kegiatan membandingkan angka-angka yang ada dalam laporan keuangan dengan cara membagi satu angka dengan angka lainnya. Perbandingan dapat dilakukan antara satu komponen dengan komponen dalam satu laporan keuangan atau antarkomponen yang ada diantara laporan keuangan. Menurut Harahap (2015:297) rasio keuangan adalah angka yang diperoleh dari hasil perbandingan dari satu pos laporan keuangandengan pos lainnya yang mempunyai hubungan yang relevan dan signifikan. Sedangkan menurut Hery (2015:162) rasio keuangan merupakan alat utama untuk melakukan analisis keuangan dan memiliki beberapa kegunaan. Rasio yang digunakan dalam penelitian ini yaitu:

1. CAR, merupakan rasio kecukupan modal yang harus dimiliki oleh Bank berdasarkan Kewajiban Penyediaan Modal Minimum (KPMM), rasio ini dirumuskan berdasarkan ketentuan Bank Indonesia No 6/23/DPNP. Rasio minimum yang harus dimiliki oleh bank yaitu $8 \%$.

2. ROA, merupakan indikator untuk mengukur kemampuan manajemen bank dalam mengelola aset yang dimiliki untuk menghasilkan laba. Semakin tinggi rasio ini menggambarkan semakin baik pengelolaan aset dalam menghasil laba yang menandakan baiknya kinerja bank.

3. NIM, merupakan rasio yang membandingkan antara pendapatan bunga neto dengan rata-rata aktiva produktif. Semakin besar rasio ini menandakan semakin besar pengelolaan aktiva produktif dalam menghasilkan pendapatan bunga. Rasio ini ditetapkan berdasarkan ketentuan Bank Indonesia No 06/23/DPNP.

4. BOPO, merupakan rasio untuk mengukur kemampuan manajemen dalam mengelola sumber daya yang dimilikinya dengan cara membandingkan biaya operasional terhadap pendapatan operasional. Rasio ini dapat digunakan untuk mengetahui efisiensi perusahaan. Semakin rendah nialai BOPO mengartikan semakin efisien pengelolaan biaya operasional perusahaan. 
5. LDR. Merupakan rasio tingkat likuiditas suatu bank dalam memenuhi dana yang ditarik masyarakat dalam bentuk simpanan tabungan, giro dan deposito (Kasmir, 2020:319). Semakin besar rasio ini mengindikasikan baiknya kinerja bank dalam mengelola dana nasabah untuk pembiayaan.

\section{Kerangka Penelitian}

Perbankan merupakan lembaga yang menjalankan fungsi ekonomi dan keuangan. Sebagai fungsi ekonomi, bank memberikan fasilitas intermediasi dari lender (pihak yang kelebihan dana) ke borrower (pihak yang memerlukan dana). Sedangkan sebagai fungsi keuangan bank memberikan fasilitas keuangan untuk memudahkan transaksi dari para pelaku ekonomi. Saat ini, terdapat dua jenis perbankan yang memberikan kontribusi nyata dalam memajukan perekonomian di Indonesia, yaitu perbankan konvensional dan perbankan syari'ah. Kedua perbankan tersebut memiliki perbedaan prinsip dalam menjalankan operasional dan tata kelolanya, sehingga menyebabkan adanya distorsi kinerja. Dari distorsi inilah peneliti mau mencoba membandingkan kinerja kedua perbankan yang ditinjau berdasarkan rasio keuangan yang terdiri dari rasio CAR, ROA, NIM, BOPO dan LDR. Hasil perbandingan akan dijadikan dasar bagi peneliti untuk menyimpulkan bahwa kinerja keuangan perbankan yang satu lebih baik dari perbankan yang lainnya yang memiliki perbedaan prinsip dalam menjalankan operasional perusahaan. Berdasarkan penjelasan tersebut, maka kerangka dalam penelitian ini yaitu :

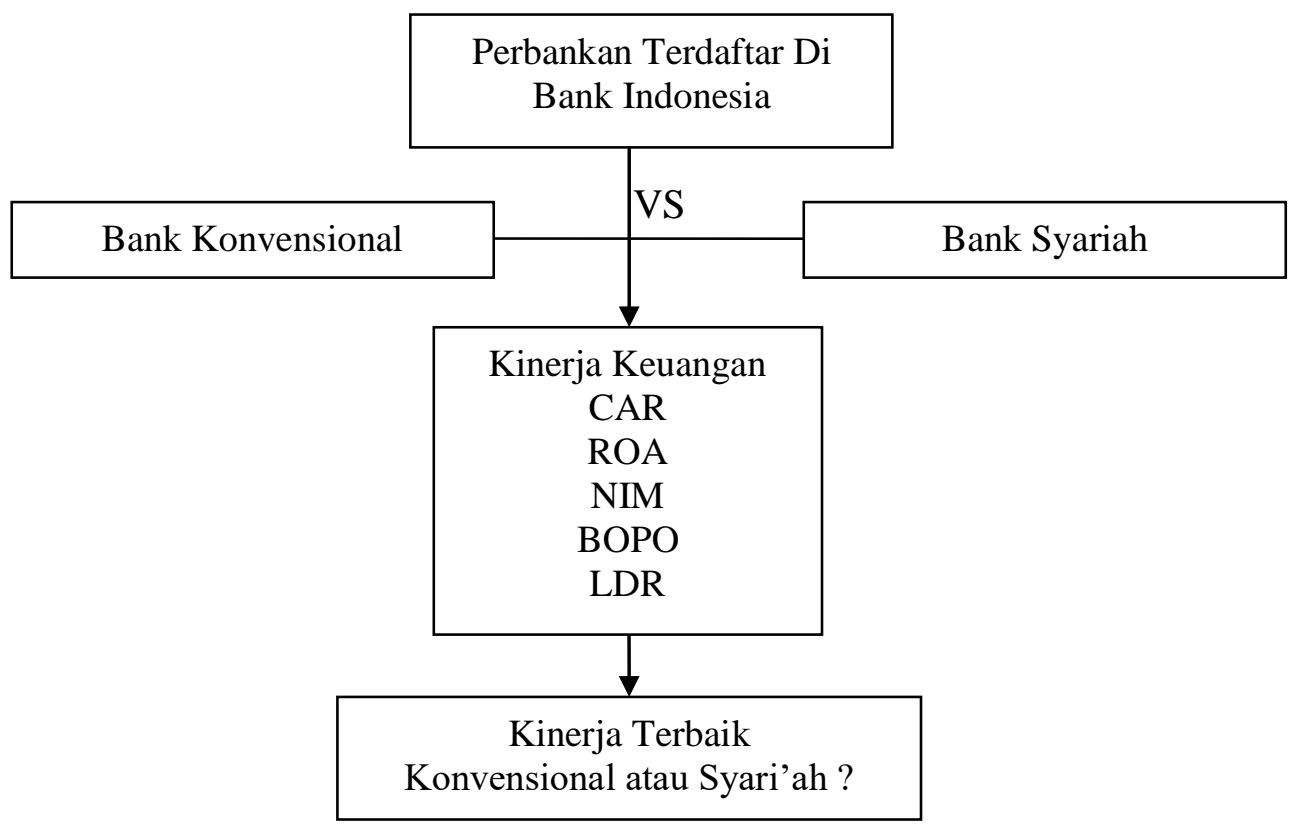

Gambar 1. Kerangka Penelitian 


\section{METODE PENELITIAN}

Desain penelitian bersifat deskriptif kuantitatif dengan unit analisisnya rasio keuangan. Metode pengambilan sampel yang digunakan yaitu purposive sampling. Pendekatan dengan metode purposive sampling yaitu teknik penentuan sample dengan menggunakan pertimbangan atau kriteria-kriteria tertentu yang telah ditetapkan sesuai dengan variabel penelitian, sehingga diperoleh 4 bank syariah dan 4 bank konvensional yang dijadikan sampel pada penelitian ini. Teknik analisis yang digunakan untuk melihat perbandingan kinerja keuangan Perbankan Syariah dan Perbankan Konvensional adalah analisis metode Independent sample t-test.

\section{Definisi dan Pengukuran Variabel Variabel Penelitian}

\section{Rasio CAR}

CAR (Capital Adequacy Ratio) adalah rasio kecukupan modal yang berfungsi menampung risiko kerugian yang kemungkinan dihadapi oleh bank. Semakin tinggi nilai CAR menandakan semakin baik kemampuan bank dalam aspek permodalan sehingga menunjukan kemampuan baik bagi bank dalam menanggung risiko dari setiap aktivitas kredit atau aktiva produktif berisiko. Nilai CAR yang tinggi menandakan bahwa bank mampu membiayai kegiatan operasionalnya dalam memberikan kontribusi perolehan profitabilitas. Rasio tersebut dapat dirusmuskan sebagai berikut (Alamsyah, 2017) :

$$
C A R=\frac{\text { Modal Bank }}{\text { Total ATMR }}
$$

Ket $: \mathrm{CAR}=$ Capital adequacy ratio; $\mathrm{ATMR}=$ aktiva tertimbang menurut rasio.

\section{Rasio ROA}

Rasio Return On Asset (ROA) ini digunakan untuk mengukur kemampuan manajemen bank dalam memperoleh keuntungan (laba) secara keseluruhan. Semakin besar ROA suatu bank, semakin besar pula tingkat keuntungan yang dicapai bank tersebut dan semakin baik pula posisi bank tersebut dari segi penggunaan asset. Rumus yang digunakan adalah (Susanto, 2015):

$$
R O A=\frac{\text { Laba Operasi }}{\text { Total Aset }}
$$

\section{Rasio NIM}

Net Interest Margin (NIM) merupakan rasio keuangan yang digunakan untuk mengukur seberapa besar kemampuan manajemen bank dalam mengelola aktiva produktifnya 
untuk menghasilkan pendapatan berupa bunga bersih. Rumus yang digunakan adalah (Pandia, 2017:71):

$$
N I M=\frac{\text { Pendapatan Bunga bersih }}{\text { rata }- \text { rata aktiva produktif }}
$$

\section{Rasio BOPO}

Rasio biaya operasional adalah perbandingan biaya operasional dan pendapatan operasional. Rasio ini digunakan untuk mengukur tingkat efisiensi dan kemampuan bank dalam melakukan kegiatan operasional. Rasio ini dapat dirumuskan sebagai berikut (Alamsyah, 2017):

$$
B O P O=\frac{\text { Biaya Operasional }}{\text { Pendapatan Operasional }}
$$

\section{Rasio LDR}

Loan to Deposit Ratio (LDR) merupakan rasio keuangan yang membandingkan antara seluruh jumlah kredit yang disalurkan bank dengan dana simpanan nasabah di bank. Rasio LDR ini digunakan untuk mengetahui besarnya kemampuan bank dalam membayarkan kembali kewajibannya kepada para nasabah yang menanamkan dananya melalui penyaluran kredit yang telah diberikan kepada para debiturnya. Semakin tinggi rasionya semakin tinggi tingkat likuiditasnya. Rasio ini dapat dirumuskan sebagai berikut (Kasmir, 2011:290) :

$$
L D R=\frac{\text { Total Pembiayaan }}{\text { Dana Pihak Ketiga }}
$$

\section{Analisis Data}

\section{Analisis Statistik Deskriptif}

Statistik deskriptif memberikan gambaran penjelasan atau deskripsi suatu data yang dilihat dari nilai maksimum, minimum, nilai rata-rata (mean), dan standar deviasi (Ghozali 2011:19).

\section{Uji Independent Sample T-Test}

Independent Sample t test adalah uji komparatif atau uji beda untuk mengetahui adakah perbedaan mean atau rerata yang bermakna antara dua kelompok bebas yang berskala data interval atau rasio. Dua kelompok bebas yang dimaksud yaitu dua kelompok yang tidak berpasangan yang artinya sumber data berasal dari subjek yang berbeda. Sebelum dilakukan uji t test (Independent Sample $t$ test) dilakukan uji kesamaan varian dengan $\mathrm{F}$ test (Levene's Test), artinya jika varian sama, maka 
penggunaan Equel Variances Assumed (diasumsikan varian sama) dan jika varian berbeda menggunakan Equel Variances Not Assumed (diasumsikan varian berbeda) (Priyanto, 2008). Pemrosesan data menggunakan SPSS (Statistical Package for the Social Science). Dengan langkah-langkah sebagai berikut :

1. Pada obyek yang diteliti dibagi kedalam dua kelompok, yaitu perbankan syariah dan perbankan konvensional.

2. Menggunakan fungsi Analyze-Compare Means-Independent Samples T Test untuk mengelola kedua kelompok tersebut.

\section{HASIL DAN PEMBAHASAN}

\section{Analisis Statistik Deskriptif}

Analisis ini memberikan gambaran tentang deskrpsi data terkait nilai minimum, maksimum, mean dan std. deviasi dari data-data rasio perbankan syari'ah dan konvensional. Adapun deskripsi data tersebut disajikan pada tabel berikut :

Tabel 2

\section{Analisis Statistik Deskriptif Bank Syariah}

\begin{tabular}{|l|c|c|c|c|c|}
\hline \multicolumn{7}{|c|}{ Descriptive Statistics } \\
\hline & $\mathrm{N}$ & Minimum & Maximum & Mean & Std. Deviation \\
\hline CAR & 16 & 12,85 & 23,53 & 17,1963 & 3,46493 \\
\hline ROA & 16 & $-3,00$ & 2,63 & 0,7050 & 1,17732 \\
\hline NIM & 16 & 5,84 & 9,34 & 7,2594 & 1,05694 \\
\hline BOPO & 16 & 86,88 & 100,60 & 93,2775 & 4,52465 \\
\hline LDR & 16 & 71,87 & 98,49 & 86,2550 & 7,62070 \\
\hline Valid N (listwise) & 16 & & & & \\
\hline
\end{tabular}

1. Pada tabel di atas dapat terlihat bahwa rasio CAR memiliki nilai minimum sebesar 12,85 , nilai maksimum sebesar 23,53, nilai std deviasi sebesar 3,46 sementara nilai rata-rata CAR sebesar 17,1963 . Hal ini mengindikasikan bahwa rata- rata nilai rasio CAR pada Bank Syariah sangat baik.

2. Pada tabel di atas dapat terlihat bahwa rasio ROA memiliki nilai minimum sebesar 0,03 , nilai maksimum sebesar 2,63, nilai std deviasi sebesar 1,17732 sementara nilai rata-rata ROA sebesar 0,705 . Hal ini mengindikasikan bahwa rata-rata nilai rasio ROA pada Bank Syariah tidak baik.

3. Pada tabel di atas dapat terlihat bahwa rasio NIM memiliki nilai minimum sebesar 5,84 , nilai maksimum sebesar 9,34, nilai std deviasi sebesar 1,05964 sementara nilai 
rata-rata NIM sebesar 7,2594. Hal ini mengindikasikan bahwa rata-rata nilai rasio NIM pada Bank Syariah sangat baik.

4. Pada tabel di atas dapat terlihat bahwa rasio BOPO memiliki nilai minimum sebesar 86,88 , nilai maksimum sebesar 100,6 , nilai std deviasi sebesar 4,52465 sementara nilai rata-rata BOPO sebesar 93,2775. Hal ini mengindikasikan bahwa rata-rata nilai rasio BOPO pada Bank Syariah tidak baik.

5. Pada tabel di atas dapat terlihat bahwa rasio LDR memiliki nilai minimum sebesar 71,87, nilai maksimum sebesar 98,49, nilai std deviasi sebesar 4,52465 sementara nilai rata-rata $\mathrm{LDR}$ sebesar 86,255 . Hal ini mengindikasikan bahwa rata-rata nilai rasio LDR pada Bank Syariah sangat baik.

Tabel 3

Analisis Statistik Deskriptif Bank Konvensional

\begin{tabular}{|l|c|c|c|c|l|}
\hline \multicolumn{7}{|c|}{ Descriptive Statistics } \\
\hline & $N$ & Minimum & Maximum & Mean & $\begin{array}{c}\text { Std. } \\
\text { Deviation }\end{array}$ \\
\hline CAR & 16 & 14,64 & 22,96 & 19,2119 & 2,38269 \\
\hline ROA & 16 & 1,14 & 4,73 & 2,8475 & 1,03054 \\
\hline NIM & 16 & 4,47 & 8,51 & 6,2319 & 1,28120 \\
\hline BOPO & 16 & 64,98 & 88,97 & 74,1763 & 7,40239 \\
\hline LDR & 16 & 81,68 & 108,86 & 91,4069 & 9,01640 \\
\hline Valid N (listwise) & 16 & & & & \\
\hline
\end{tabular}

1. Pada tabel di atas dapat terlihat bahwa rasio CAR memiliki nilai minimum sebesar 14,64, nilai maksimum sebesar 22,96, nilai std deviasi sebesar 2,38269 sementara nilai rata-rata CAR sebesar 19,2119. Hal ini mengindikasikan bahwa rata-rata nilai rasio CAR pada Bank Konvensional sangat baik.

2. Pada tabel di atas dapat terlihat bahwa rasio ROA memiliki nilai minimum sebesar 1,14, nilai maksimum sebesar 4,73, nilai std deviasi sebesar 1,03054 sementara nilai rata-rata ROA sebesar 2,8475. Hal ini mengindikasikan bahwa rata-rata nilai rasio ROA pada Bank Konvensional sangat baik.

3. Pada tabel di atas dapat terlihat bahwa rasio NIM memiliki nilai minimum sebesar 4,47, nilai maksimum sebesar 8,51, nilai std deviasi sebesar 1,2812 sementara nilai rata-rata NIM sebesar 6,2319. Hal ini mengindikasikan bahwa rata-rata nilai rasio NIM pada Bank Konvensional sangat baik.

4. Pada tabel di atas dapat terlihat bahwa rasio BOPO memiliki nilai minimum sebesar 64,98, nilai maksimum sebesar 88,97, nilai std deviasi sebesar 7,40239 
sementara nilai rata-rata BOPO sebesar 74,1763. Hal ini mengindikasikan bahwa rata-rata nilai rasio BOPO pada Bank Konvensional sangat baik.

5. Pada tabel di atas dapat terlihat bahwa rasio LDR memiliki nilai minimum sebesar 81,68, nilai maksimum sebesar 108,86, nilai std deviasi sebesar 9,0164 sementara nilai rata-rata LDR sebesar 91,4069. Hal ini mengindikasikan bahwa rata-rata rasio LDR pada Bank Konvensional sangat baik.

\section{Uji Independen Sampel T-test}

Digunakan untuk melihat apakah terdapat perbedaan secara signifikan kinerja keuangan perbankan syari'ah dengan perbankan konvensional. Hal ini akan ditunjukan melalui nilai sig.(2-taled) dari hasil pengujian statistik yang telah dilakukan. Adapun hasil pengujian independent samples t-test dapat dilihat pada tabel di bawah ini :

\section{Tabel 5}

Uji Independent Sample T-test.

\begin{tabular}{|c|c|c|c|c|c|c|}
\hline \multicolumn{7}{|c|}{ Independent Samples Test } \\
\hline & & \multicolumn{2}{|c|}{$\begin{array}{l}\text { Levene's } \\
\text { Test for } \\
\text { Equality of } \\
\text { Variances }\end{array}$} & \multicolumn{3}{|c|}{ t-test for Equality of Means } \\
\hline & & $\mathbf{F}$ & Sig. & $\mathbf{T}$ & Df & Sig. (2-tailed) \\
\hline \multirow[b]{2}{*}{ CAR } & Equal variances assumed & 5,520 & ,026 & 1,917 & 30 & ,065 \\
\hline & Equal variances not assumed & & & 1,917 & 26,594 & ,066 \\
\hline \multirow[b]{2}{*}{ ROA } & Equal variances assumed & 3,087 & ,089 & 6,324 & 30 &, 000 \\
\hline & Equal variances not Assumed & & & 6,324 & 26,106 & 000 \\
\hline \multirow[t]{2}{*}{ NIM } & Equal variances assumed & ,089 &, 768 & $-2,475$ & 30 & 019 \\
\hline & Equal variances not assumed & & & $-2,475$ & 28,954 & ,019 \\
\hline \multirow[b]{2}{*}{ BOPO } & Equal variances assumed & 5,011 & ,033 & $-8,807$ & 30 &, 000 \\
\hline & Equal variances not assumed & & & $-8,807$ & 24,836 & 000 \\
\hline \multirow[t]{2}{*}{ LDR } & Equal variances assumed &, 154 & ,698 & 1,746 & 30 & ,091 \\
\hline & Equal variances not assumed & & & 1,746 & 29,190 & ,091 \\
\hline
\end{tabular}

\section{Sumber data : hasil pengujian SPSS, 2019}

Berdasarkan tabel diatas, setelah dilakukan pengujian dengan menggunakan $U j i$ Kolmogorov-Smirnov menghasilkan besarnya nilai Kolmogorov-Smirnov adalah 0,087 dan Asymp. Sig. (2-tailed) pada 0,200. Data dikatakan normal apabila nilai

1. Nilai F hitung untuk CAR adalah 5.520 dengan probabilitas 0.026 , karena probabilitas data di atas < 0.05 maka dasar yang digunakan adalah equal variance not assumed (diasumsi kedua varians tidak sama) . t hitung untuk CAR dengan menggunakan 
equal variance not assumed adalah 1.197 dengan probabilitas sebesar 0,66. Oleh karena probabilitas data di atas lebih besar dari 0,05, maka dapat dikatakan bahwa rasio CAR tidak terdapat perbedaan yang siginifikan antara kinerja keuangan Bank Syariah dengan Bank Konvensional.

2. Nilai F hitung untuk ROA adalah 3.087 dengan probabilitas 0.089 , karena probabilitas data di atas > 0.05 maka dasar yang digunakan adalah equal variance assumed (diasumsi kedua varians sama) . thitung untuk ROA dengan menggunakan equal variance assumed adalah 6.324 dengan probabilitas sebesar 0,000. Oleh karena probabilitas data di atas lebih kecil dari 0,05, maka dapat dikatakan bahwa rasio ROA terdapat perbedaan yang siginifikan antara kinerja keuangan Bank Syariah dengan Bank Konvensional.

3. Nilai F hitung untuk NIM adalah 0.089 dengan probabilitas 0.768, karena probabilitas data di atas > 0.05 maka dasar yang digunakan adalah equal variance assumed (diasumsi kedua varians sama) . thitung untuk NIM dengan menggunakan equal variance assumed adalah -2.475 dengan probabilitas sebesar 0,019. Oleh karena probabilitas data di atas lebih kecil dari 0,05, maka dapat dikatakan bahwa rasio NIM terdapat perbedaan yang siginifikan antara kinerja keuangan Bank Syariah dengan Bank Konvensional.

4. Nilai F hitung untuk BOPO adalah 5.011 dengan probabilitas 0.033, karena probabilitas data di atas $<0.05$ maka dasar yang digunakan adalah equal variance not assumed (diasumsi kedua varians tidak sama) . t hitung untuk BOPO dengan menggunakan equal variance not assumed adalah -8.807 dengan probabilitas sebesar 0,000. Oleh karena probabilitas data di atas lebih kecil dari 0,05, maka dapat dikatakan bahwa rasio BOPO terdapat perbedaan yang siginifikan antara kinerja keuangan Bank Syariah dengan Bank Konvensional.

5. Nilai $F$ hitung untuk LDR adalah 0.154 dengan probabilitas 0.698, karena probabilitas data di atas > 0.05 maka dasar yang digunakan adalah equal variance assumed (diasumsi kedua varians sama) . thitung untuk LDR dengan menggunakan equal variance assumed adalah 1.746 dengan probabilitas sebesar 0,091. Oleh karena probabilitas data di atas lebih besar dari 0,05, maka dapat dikatakan bahwa rasio LDR tidak terdapat perbedaan yang siginifikan antara kinerja keuangan Bank Syariah dengan Bank Konvensional. 


\section{KESIMPULAN}

Berdasarkan hasil pengujian statistik melalui pengujian Independen sample ttes, diperoleh hasil bahwa :

1. rasio CAR tidak terdapat perbedaan yang signifikan antara kinerja keuangan perbankan syariah dengan perbankan konvensional. Namun Bank Syariah mempunyai mean rasio CAR sebesar 17,1963\%, lebih kecil dibandingkan dengan mean rasio CAR Bank Konvensional sebesar 19,211\%. Akan tetapi rasio CAR Bank Syariah masih berada di atas kriteria kondisi baik yang ditetapkan Bank Indonesia, yaitu melebihi $8 \%$.

2. Rasio ROA terdapat perbedaan yang signifikan antara kinerja keuangan perbankan syariah dengan perbankan konvensional. Bank Syariah mempunyai mean rasio ROA sebesar 0,7050\%, lebih kecil dibandingkan dengan mean rasio ROA Bank Konvensional sebesar 2,8475\%. Rasio ROA Bank Syariah berada pada kondisi yang tidak ideal karena berada di bawah ketentuan Bank Indonesia. yaitu diatas $1,5 \%$.

3. Rasio NIM terdapat perbedaan yang signifikan antara kinerja keuangan perbankan syariah dengan perbankan konvensional. Bank Syariah mempunyai mean rasio NIM sebesar 7,2594\%, lebih besar dibandingkan dengan mean rasio NIM Bank Konvensional sebesar 6,2319\%. Rasio NIM Bank Syariah dan Bank Konvensional berada di bawah kriteria kondisi baik yang ditetapkan Bank Indonesia, yaitu di bawah 5\%.

4. Rasio BOPO terdapat perbedaan yang signifikan antara kinerja keuangan perbankan syariah dengan perbankan konvensional. Bank Syariah mempunyai mean rasio BOPO sebesar 93,2775\%, lebih kecil dibandingkan dengan mean rasio BOPO Bank Konvensional sebesar 74,1763\%. Rasio BOPO Bank Syariah berada pada kondisi yang tidak ideal karena berada di bawah ketentuan Bank Indonesia. yaitu diatas $92 \%$.

5. Rasio LDR tidak terdapat perbedaan yang signifikan antara kinerja keuangan perbankan syariah dengan perbankan konvensional. Bank Syariah mempunyai mean rasio sebesar LDR 86,255\% dan mean rasio LDR Bank Konvensional sebesar 91,4069\%. Akan tetapi rasio LDR Bank Syariah masih berada di atas kriteria kondisi baik yang ditetapkan Bank Indonesia, yaitu 85\%-110\%. 


\section{DAFTAR PUSTAKA}

Alamsyah, Sustari. 2017. Pengaruh Capital Adequacy Ratio (CAR), Non Performing Loan (NPL), Loan to Deposite Ratio (LDR), Return On Asset (ROA) dan Net Interest Margin (NIM) Terhadap Pertumbuhan Laba. Jurnal Competitive, Vol 2, Issue 1, Hal 32-54.

Angraini, 2012. Analisis Perbandingan Kinerja Keuangan Perbankan Syariah dengan Perbankan Konvensional. Fakultas Ekonomi Universitas Hasanudin.

Angel, Christania Graciella dan Rudy J.Pusung, 2014. Analisis Perbandingan Kinerja pada Bank Nasional dan Bank Asing Dengan Menggunakan Analisis Rasio Keuangan. Fakultas Ekonomi Universitas Sam Ratulangi.

Antonio, Muhammad Syafi'i. 2014. Bank Syariah: Dari Teori Ke Praktik. Jakarta: Gema Insani.

Ardyana, Vynna. 2017. Analisis Perbandingan Kinerja Keuangan pada Bank Syariah dan Bank Konvensional. Fakultas Ekonomi Universitas Muhammadiyah Surakarta.

Arianto, D. 2016. Analisis Perbandingan Kinerja Keuangan Bank Konvensional Dan Bank Syari'ah Periode 2010-2014. E-Jurnal Akuntansi Universitas Udayana., Vol 15, No 1.

https://www.cnbcindonesia.com/market/20210120194700-17-217559/putusan-ptuntak-berdampak-terhadap-transformasi-bukopin

Damayanti, Ria Tuzi. 2013. Analisis Perbandingan Kinerja Keuangan Bank Syariah dan Bank Konvensional. Fakultas Ekonomi Institut Pertanian Bogor.

Faqihuddin, Ahmad Nur. 2011. Analisis Kinerja Keuangan Bank Umum Syariah dan Bank Konvensional yang Memiliki Unit Usaha Syariah. Fakultas Syariah dan Hukum Universitas Islam Negeri Sunan Kalijaga.

Ghozali, Imam. 2016. Aplikasi Analisis Multivariete Dengan Program IBM SPSS 23 (Edisi 8). Cetakan ke VIII. Semarang : Badan Penerbit Universitas Diponegoro.

Hanafi, Mamduh M,. Dan Abdul Halim. 2009. Analisis Laporan Keuangan (Edisi Keempat). Cetakan ke 2. Yogyakarta : UPP STIM YKPN.

Hery. 2017. Cara Cepat dan Mudah Memahami Pengantar Manajemen. Yogyakarta : Gava Media. 
Kasman, A., \& Carvallo, O. (2013). Efficiency and risk in Latin American Banking: Explaining Resilience. Emerging Markets Finance and Trade, 49(2).

Kasmir. 2010. Pengantar Manajemen Keuangan (Edisi Kesatu). Cetakan ke 1. Jakarta : KENCANA PRENADA MEDIA GROUP.

Kasmir. 2011. Dasar-Dasar Perbankan. Jakarta: PT. Raja Grafindo Persada.

Pandia, Frianto. 2012. Manajemen Dana Dan Kesehatan Bank. Jakarta: Rineka Cipta

Rudianto. 2013. Akuntansi Manajemen Informasi untuk Pengambilan Keputusan Strategis. Jakarta: Erlangga

Sovia, Sasa Elida. Muhammad Saifi dan Achmad Husaini, 2016. Analisis Kinerja Keuangan Bank Konvensional dan Bank Syariah berdasarkan Rasio Keuangan Bank. Fakultas Ilmu Administrasi Universitas Brawijaya.

Susanto, Joko. 2015. Pengaruh Capital Adequacy Ratio, Non Performing Loan, Loan to Deposit Ratio, Return On Asset, Biaya Operasional terhadap Pendapatan Operasinal dan Total Asset Turnover Terhadap Perubahan Laba. Jurnal Akuntansi dan Sistem Teknologi Informasi. (Vol. 11 No. 2 September: 226 -233)

Tara, M Amrullah Reza Putra. 2014. Analisis Perbandingan Kinerja Keuangan Perbankan Syariah Menggunakan Pendekan Laba Rugi (Income Statement) dan Nilai Tambah (Value Added Statement). Fakultas Ekonomi Universitas Diponegoro 